\title{
The Kingdom of Rus'
}




\section{PAST IMPERFECT}

Past Imperfect presents concise critical overviews of the latest research by the world's leading scholars. Subjects cross the full range of fields in the period ca. 400-1500 CE which, in a European context, is known as the Middle Ages. Anyone interested in this period will be enthralled and enlightened by these overviews, written in provocative but accessible language. These affordable paperbacks prove that the era still retains a powerful resonance and impact throughout the world today.

\section{Director and Editor-in-Chief}

Simon Forde, Western Michigan University

\section{Acquisitions Editors}

Erin Dailey, Leeds

Ruth Kennedy, Adelaide

\section{Production}

Ruth Kennedy, Adelaide 


\section{The Kingdom of Rus'}

\section{Christian Raffensperger}




\section{Library of Congress Cataloging in Publication Data}

Names: Raffensperger, Christian, author.

Title: Kingdom of Rus' / by Christian Alexander Raffensperger.

Description: Kalamazoo, MI : Medieval Institute Publications, [2017] |

Series: Past imprfect | Includes bibliographical references.

Identifiers: LCCN 2017035090 (print) | LCCN 2017035652 (ebook) | ISBN

9781942401339 | ISBN 9781942401315 (pbk. : alk. paper)

Subjects: LCSH: Kievan Rus--Kings and rulers--History. | Nobility--Kievan

Rus. | Kievan Rus--Relations--Europe. | Europe--Relations--Kievan Rus.

Classification: LCC DK73 (ebook) | LCC DK73 .R238 2017 (print) | DDC

947/.02--dc23

LC record available at https://lccn.loc.gov/2017035090

\section{(C) 2017, Arc Humanities Press, Kalamazoo and Bradford}

Permission to use brief excerpts from this work in scholarly and educational works is hereby granted provided that the source is acknowledged. Any use of material in this work that is an exception or limitation covered by Article 5 of the European Union's Copyright Directive (2001/29/EC) or would be determined to be "fair use" under Section 107 of the U.S. Copyright Act September 2010 Page 2 or that satisfies the conditions specified in Section 108 of the U.S. Copyright Act (17 USC §108, as revised by P.L. 94-553) does not require the Publisher's permission.

ISBN (print): 9781942401315

eISBN (PDF): 9781942401322

elSBN (EPUB): 9781942401339

arc-humanities.org 
For Iris and Malcolm 
